\title{
Cystic fibrosis transmembrane conductance regulator (CFTR) inhibition results in mucus accumulation in human airway epithelia Calu-3 cells: Experimental and Machine Learning Studies
}

Brandon S. Laethem ${ }^{1}$, Kenneth T. Lewis ${ }^{1,2}$, Rafael Ramos ${ }^{1,2}$, Xia Hou ${ }^{1}$, Fei Sun ${ }^{1}$, Douglas J.

${ }^{1}$ Department of Physiology, School of Medicine, ${ }^{2}$ NanoBioScience Institute, ${ }^{3}$ Center for Molecular Medicine \& Genetics, School of Medicine; ${ }^{3}$ Department of Computer Science, College of Engineering, Computing \& Information Technology, High Performance Computing, Wayne State University, Detroit, MI 48201, USA; ${ }^{4}$ Department of Pathology and Medicine, Burlington, VT 05405, USA

$\$$ These authors contributed equally to the study.

\section{ORCID}

KEYWORDS: CFTR, Calu-3 cells, Mucus secretion, EM morphometry, machine learning, 


\section{ABSTRACT}

32 Porosomes are cup-shaped lipoprotein structures at the cell plasma membrane involved in

33 fractional release of intra-vesicular contents during secretion. At the base of the porosome

34 facing the cell cytoplasm, secretory vesicles dock, fuse and swell, to release intra-vesicular content during secretion. Earlier studies demonstrate the cystic fibrosis trans-membrane conductance regulator (CFTR) associated with the porosome in human airways epithelial Calu3 mucous-secreting cells, suggesting its possible involvement in porosome-mediated mucus secretion. The current study was undertaken to test this hypothesis. Electron microscopy followed by morphometric analysis using manual and computational machine learning approaches were used to assess changes in secretory vesicle size and content, following stimulation of secretion in the absence and presence of CFTR inhibitors. Results from the study demonstrate that stimulated Calu-3 cells pre-exposed to CFTR inhibitors, demonstrate attenuation of secretory vesicle swelling and the release of mucin. Consequently, accumulation of intracellular mucin is observed in cells exposed to CFTR inhibitors. These results further suggest that mucin secretion from Calu-3 cells involve CFTR both at the secretory vesicle membrane to regulate vesicle volume and hydration, and at the porosome to facilitate mucin hydration and secretion. These new findings progress our understanding of the involvement of CFTR on mucus hydration and secretion, providing critical insights into the etiology of CF disease. 


\section{INTRODUCTION}

60 All living organisms, from yeast to cells in humans depend on secretion to release

61 intracellular products beyond the confines of the cells outer membrane. In mammalian cells,

62 secretion involves the docking, swelling and transient fusion of secretory vesicles at cup-

63 shaped plasma membrane lipoprotein structures called porosomes, for the regulated expulsion

64 of intra-vesicular contents to the interstitium [1-28]. Secretory vesicles dock and fuse [29-37],

65 and undergo swelling involving the transport of water and ions into the secretory vesicle [38-

$6644]$. Vesicle swelling result in hydration and a buildup of intra-vesicular pressure, required

67 for content expulsion during cell secretion. Greater pressure translates to increased intra-

vesicle membrane and the cell plasma membrane, while precisely regulating intra-vesicular

content release [45-47] during cell secretion. The cup-shaped porosomes range in size from

$15 \mathrm{~nm}$ in neurons and astrocytes, to $100-180 \mathrm{~nm}$ in endocrine and exocrine cells. Porosomes

in Calu-3 cells measure approximately $100 \mathrm{~nm}$ and are composed of nearly 34 proteins

among them the cystic fibrosis trans-membrane conductance regulator (CFTR) [48],

compared to the nuclear pore complex of similar dimension and nearly 1,000 protein

molecules [49]. Human airways epithelium is coated with a thin film of mucus, composed

76 primarily of mucin. Mucus is continually moved via ciliary action and cleared. In addition to

77 lubricating the airways, mucus serves to trap foreign particles and pathogens, assisting in

78 keeping the airways free of infection. Mucus hydration has been recognized as a problem in 
cystic fibrosis $(\mathrm{CF})$, and therefore we posit that altered mucin secretion either due to increased viscosity of the secreted mucin or attenuated secretion, would results in the

81 inability of the cilia to propel mucin, leading to its stagnation in the airways and to infections

and GlyH101 [50], to determine changes in secretory vesicle size and content (filled vs empty). Transmission electron microscopy followed by morphometry of the electron micrographs performed both manually and using computation machine learning approach, were used to determine changes in mucin secretion.

\section{MATERIALS AND METHODS}

\subsection{Calu-3 cell culture}

91 Airways epithelial Calu-3 cells are derived from a human lung adenocarcinoma [51]. The

92 cells were grown in Dulbecco's Modified Eagle Medium: Nutrient Mixture F-12 (DMEM/F-

93 12) (Invitrogen) containing 15\% fetal bovine serum. Cells were incubated in a humidified

94 atmosphere at $37^{\circ} \mathrm{C}$ and $5 \% \mathrm{CO}_{2}$.

\section{$2.2 \quad$ Stimulation of Calu-3 cells}

97 Stimulation experiments were performed on Calu-3 cells grown to confluency in an air-liquid 98 interface on permeable filter supports. Calu-3 cells were seeded on Costar Transwell 
permeable supports (Costar, Corning) in DMEM:F12 (Sigma-Aldrich, St.Louis.MO, USA),

$103 \mathrm{CaCl}_{2}, 1.2 \mathrm{mM} \mathrm{MgCl} 2,1.2 \mathrm{KH}_{2} \mathrm{PO}_{4}, 0.8 \mathrm{mM} \mathrm{K}_{2} \mathrm{HPO}_{4}$ and 11.2 glucose) that was

107 after plating cells and the apical compartment containing cells was exposed to air. The medium $(0.5 \mathrm{ml})$ in the basolateral compartment was changed every 2-3 days. After

111 holder. Ringer's buffer is added to the apical side of the chamber and low Ringer's $(60 \mathrm{mM}$

112 Sodium Gluconate, $25 \mathrm{mM} \mathrm{NaHCO} 3,1.2 \mathrm{mM} \mathrm{CaCl}_{2}, 1.2 \mathrm{mM} \mathrm{MgCl}_{2}, 1.2 \mathrm{mM} \mathrm{KH} \mathrm{KHO}_{4}$,

$1130.8 \mathrm{mM} \mathrm{K}_{2} \mathrm{HPO}_{4}$ and $11.2 \mathrm{mM}$ glucose) to the basolateral compartment. $I_{\mathrm{sc}}$ was measured by

114 voltage clamping. Once a stable basal point was established, $10 \mu \mathrm{M}$ Forskolin was added to

115 the basolateral compartment to induce channel opening. When the CFTR channels reach a

116 stable activation threshold, $10 \mu \mathrm{M}$ inhibitor GyH101 was added to inhibit channel activity.

\subsection{Electron microscopy}

119 Transmission electron microscopy of forskolin-stimulated Calu-3 cells in the presence and

120 absence of the CFTR inhibitors GlyH101 and Inh172, were prefixed for $2 \mathrm{~h}$ in $4 \%$ PFA and

121 then stored in 2\% PFA until further processing was performed. Briefly, cells were further 
122 fixed in half-strength Karnovsky's fixative (1.5\% glutaraldehyde, $1.0 \%$ formaldehyde in

$1230.1 \mathrm{M}$ cacodylate buffer, for 80 minutes at $4^{\circ} \mathrm{C}$, followed by post-fixation for $1 \mathrm{~h}$ at $4^{\circ} \mathrm{C}$ in $1 \%$

$124 \mathrm{OsO}_{4}$ in $0.1 \mathrm{M}$ cacodylate buffer. The sample was then dehydrated in a graded series of

125 ethanol through propylene oxide and infiltrated and embedded in Spurr's resin. Ultrathin

126 sections were cut with a diamond knife, retrieved onto grids, and contrasted with alcoholic

127 uranyl acetate and lead citrate. Grids were viewed with a JEOL 1400 transmission electron

128 microscope (JEOL USA, Inc., Peabody, MA) operating at $80 \mathrm{kV}$, and digital images were

129 acquired with an AMT-XR611 11 megapixel ccd camera (Advanced Microscopy Techniques,

130 Danvers, MA).

131

$132 \quad 2.4 \quad$ Manual and deep learning algorithms for morphometric analysis

133 ImageJ image processing software was used to manually demarcate the outline of cells and

134 secretory vesicles within electron micrographs of forskolin-stimulated Calu-3 cells in the

135 presence and absence of the CFTR inhibitors GlyH101 and Inh172, and under identical

136 magnification, were used to determine changes in vesicle size and contents within cells. This

137 manual morphometric measurement was complemented by a machine-learning framework

138 developed to understand the morphometry and content of the secretory vesicles in the

139 presence of the two CFTR inhibitors (GlyH101 and Inh 172). In particular, a deep learning 
bioRxiv preprint doi: https://doi org/10.1101/2020.05.26.117853; this version posted May 27, 2020. The copyright holder for this preprint (which was not certified by peer review) is the author/funder, who has granted bioRxiv a license to display the preprint in perpetuity. It is made available under aCC-BY 4.0 International license.

140 segmentation method based on a ResNet-101 network architecture [52-54] was employed,

141 that allows the automatic detection of secretory vesicles.

142

143 3. RESULTS AND DISCUSSION

144 Ussing chamber studies demonstrate the presence of a functional CFTR in Calu-3 cells

145 [Figure 1]. When exposed to $10 \mu \mathrm{M}$ Forskolin, Calu-3 cells release chloride, which is

146 attenuated in the presence of the two CFTR inhibitors (GlyH101 and Inh 172). Manual

147 demarcation of cells and secretory vesicles in electron micrographs of Calu-3 cells under

148 identical magnification demonstrate a loss of intra-vesicular contents following stimulation of

149 secretion. In contrast, cells pre-exposed to CFTR inhibitors reflect little loss of vesicle

150 contents following stimulation of secretion [Figures 2-4].

151

Calu-3 Cells

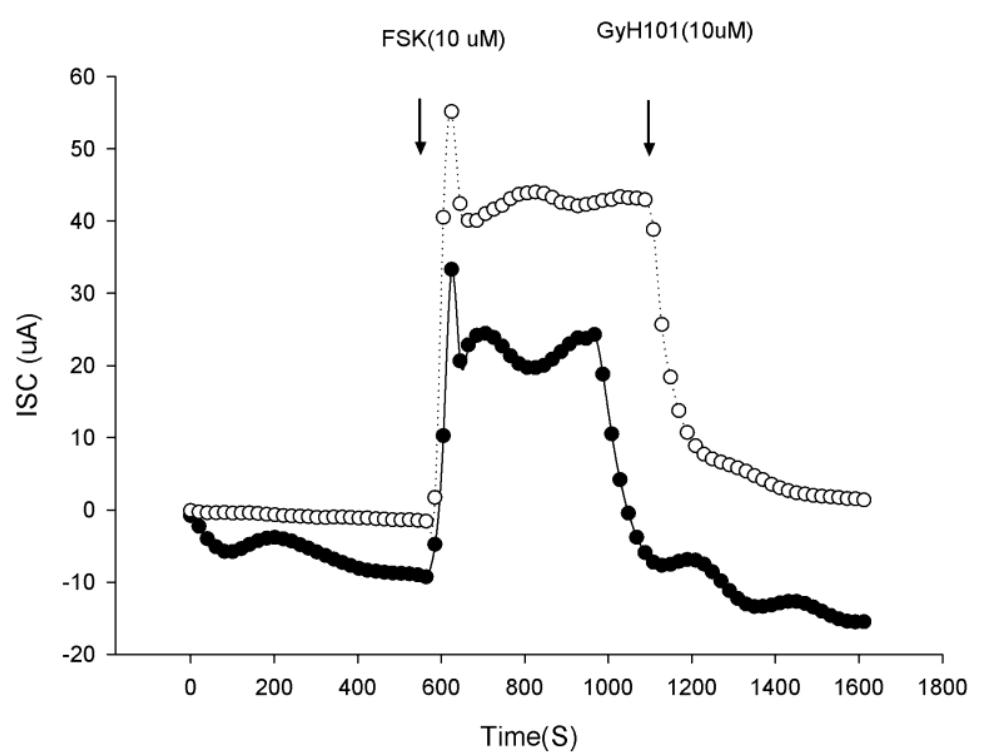

152 
bioRxiv preprint doi: https://doi org/10.1101/2020.05 26.117853; this version posted May 27, 2020. The copyright holder for this preprint (which was not certified by peer review) is the author/funder, who has granted bioRxiv a license to display the preprint in perpetuity. It is made available under aCC-BY 4.0 International license.

153 Figure 1. Ussing chamber experiments showing Forskolin-stimulated chloride release from

154 Calu-3 cells which is inhibited in the presence of the CFTR inhibitor GlyH-101. Note that the

155 two separate experiments demonstrate similar stimulation and inhibition profiles.

156

157

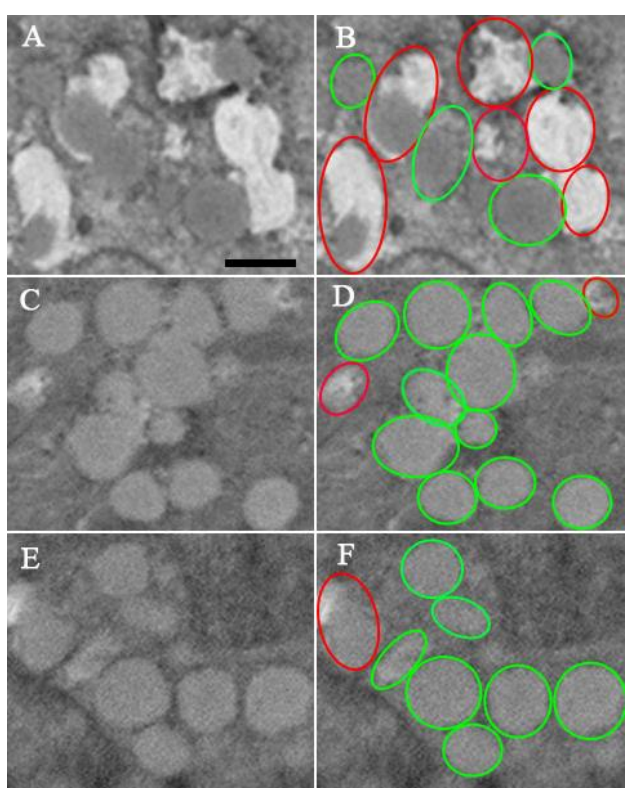

158 Figure 2. CFTR inhibitors 172 and GlyH-101 inhibit forskolin-stimulated secretion of intra-

159 vesicular mucin from Calu-3 cells. A and B are from the control cell, C and D are from cells

160 exposed to 172, and $\mathrm{E}$ and $\mathrm{F}$ are from cells exposed to GlyH-101. The vesicles outlined in red

161 are the partial/ empty vesicles and those outlined in green are the filled vesicles. Scale bar = 


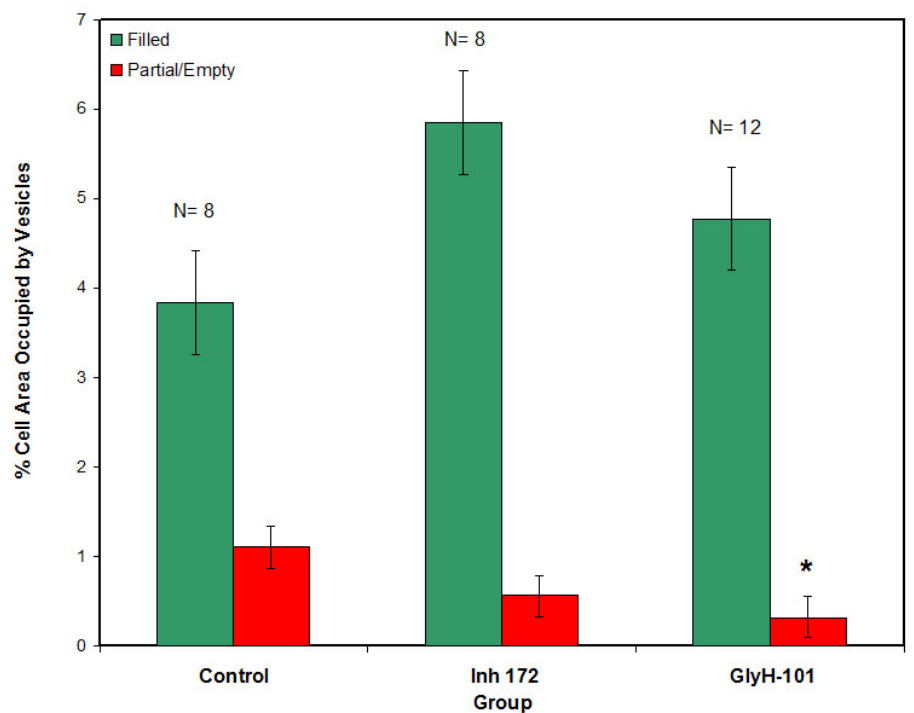

165 Figure 3. Manual morphometry demonstrates that exposure of Calu-3 cells to the CFTR inhibitors GlyH-101 inhibit stimulated secretion from Calu-3 cells. Note the significant

$167 \quad(* \mathrm{p}<0.05)$ loss of secretion and retention of intra-vesicular contents in Calu-3 cells exposed to 168 GlyH-101.

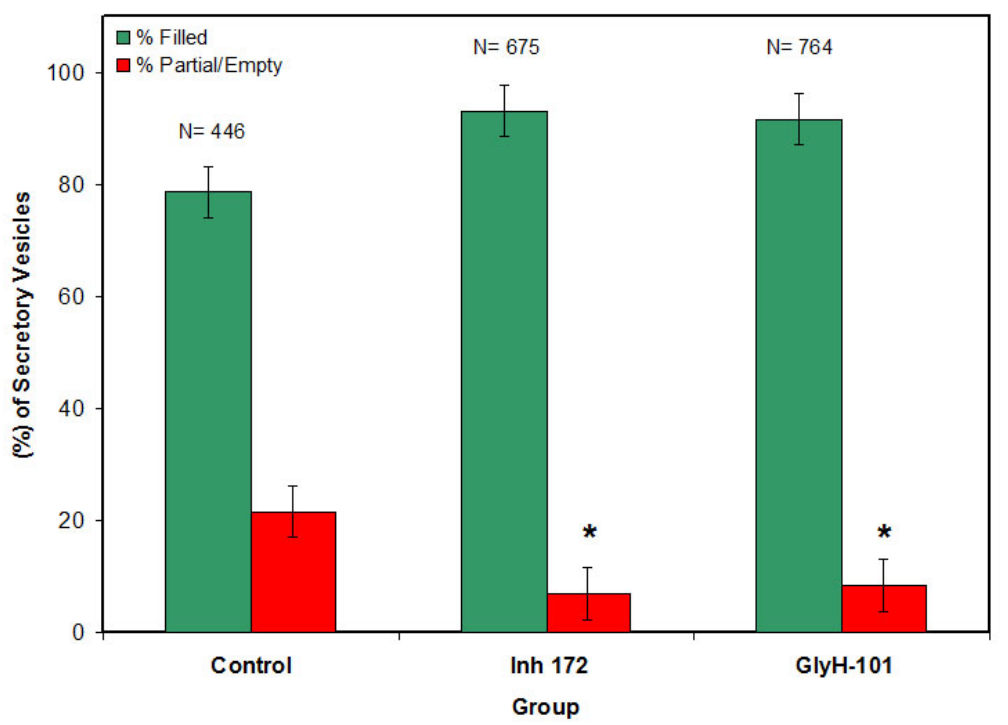

171 Figure 4. Manual morphometry of secretory vesicles demonstrates that exposure of Calu-3 


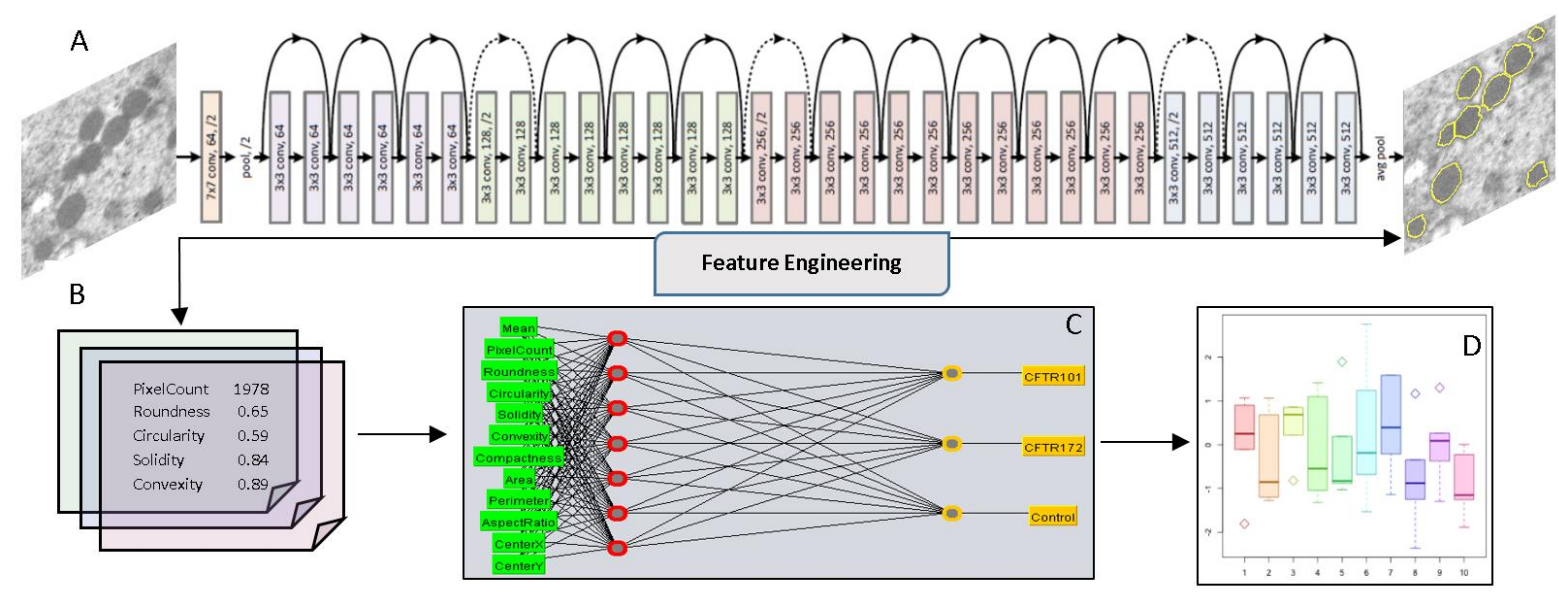

176 Figure 5. Computational Analysis Framework. A. Deep Learning based segmentation usi ng a ResNet-101 network architecture; B. Parameters obtained through computational im age analysis and feature engineering; C. The artificial Neural Network (ANN) architectur e that differentiates vesicles in the control and CFTR inhibited Calu-3 cells using paramet ers obtained in Step B; D. Identification of significant parameters associated with the ch anges in secretory vesicle content in control, and in the presence of the two CFTR inhib itors.

184 Here, we built a framework [Figure 5] to understand the morphometry and content of the secretory vesicles in the presence of the two CFTR inhibitors (GlyH101 and Inh 172). In particular, we have built a deep learning based segmentation method on a ResNet-101 network architecture [52-54] that allows the detection of the objects of interest, i.e. the secretory vesicles. Object segmentation refers to the task of grouping pixels that define an object and requires the annotation of several foreground and background objects to perform a supervised learning task. The partial and filled secretary vesicles in multiple Calu-3 cells are annotated manually and pixel-by-pixel as foreground objects. During training, the model 
192 "learns" to distinguish the foreground objects from the background. A separate model is

193 trained for control and each CFTR inhibited cells. Once the fully trained ResNet-101 models

194 are constructed based on the labeled data, new Calu-3 cell images are fed into the network to

195 automatically annotate each pixel and determine the group of pixels representing the vesicles.

196 Figure 6 shows the segmentation of partial and filled secretory vesicles on control and CFTR

197 inhibited images using our computational approach. Next, the features associated with each

198 secretory vesicle are estimated using computational image analysis. The extracted features

199 are; the average amount of gray intensity, minimum intensity, maximum intensity, standard

200 deviation of the intensity, number of pixels within the object area,

201 roundness $\sqrt{\left(=\frac{4 * \text { Area }^{2}}{\pi * \text { maxDiameter }}{ }^{2}\right.}$, compactness $\sqrt{\left(=\frac{\sqrt{\frac{4 * \text { Area }}{\pi}}}{\text { maxDiameter }}\right)}$, circularity $\sqrt{\left(=\frac{4 * \text { Area } * \pi_{\text {Perimeter }}^{2}}{2}\right)}$,

202 solidity $\left(=\frac{\text { Area }}{\text { Convex Area }}\right)$, convexity $\longdiv { ( = \frac { \text { Convex Perimeter } } { \text { Perimeter } } ) }$, area, perimeter and aspect ratio, and

203 the $\mathrm{x}$ - and $\mathrm{y}$-coordinates of the center of each object. 
bioRxiv preprint doi: https://doi org/10.1101/2020.05.26.117853; this version posted May 27, 2020. The copyright holder for this preprint (which was not certified by peer review) is the author/funder, who has granted bioRxiv a license to display the preprint in perpetuity. It is made available under aCC-BY 4.0 International license.

Secretory Vesicles
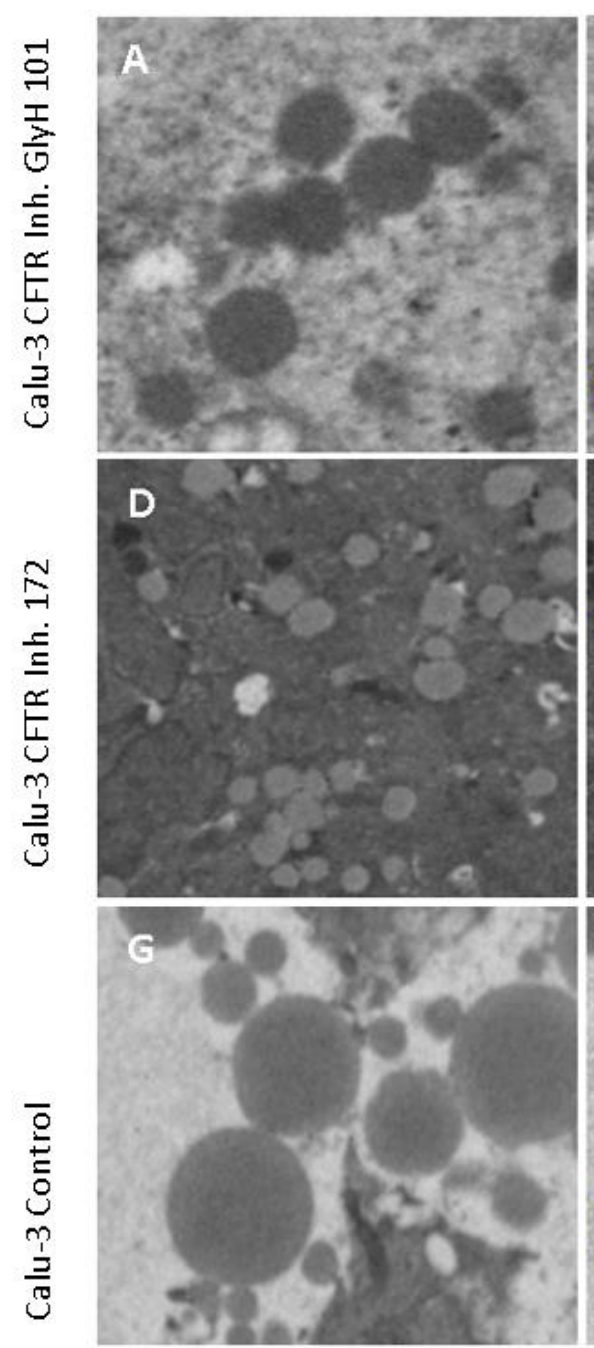

Filled
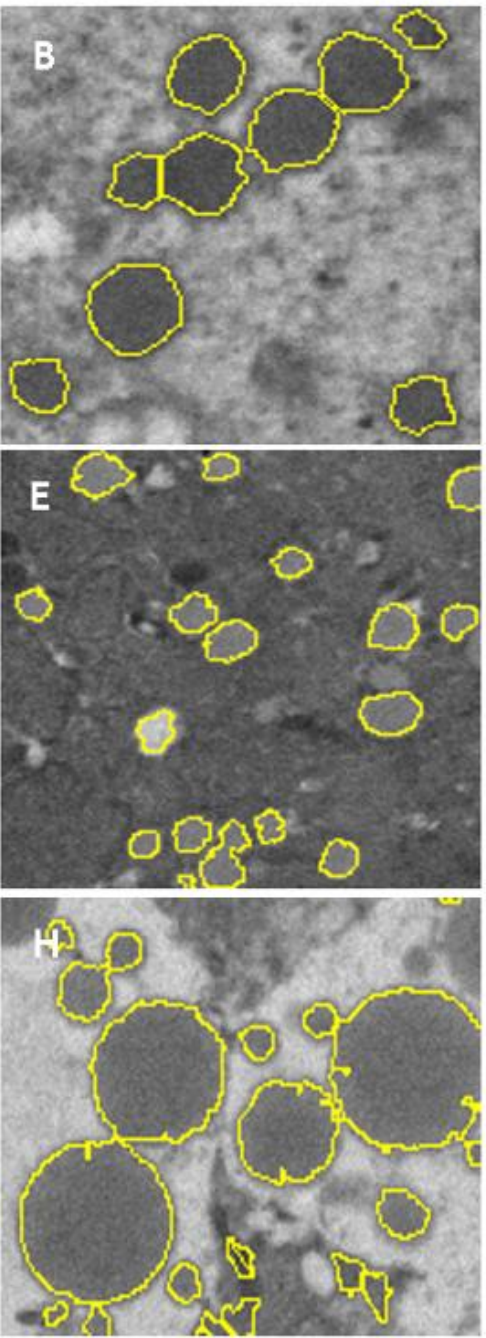

Partial/Empty
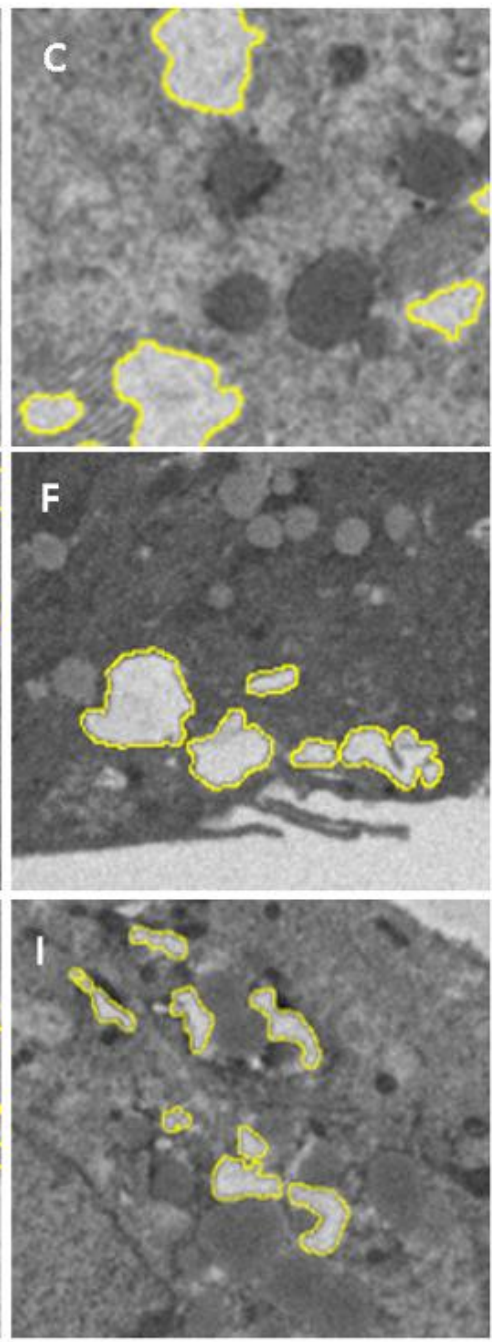

Figure 6. Filled and partially filled/empty secretory vesicles (scale bar $=2 \mathrm{um}$ ). A. Gly

211 on in control; I. Partially filled/empty vesicle segmentation in control.

213 The extracted features are then fed into an artificial neural network (ANN) that differentiates

214 the vesicles in the control and CFTR inhibited Calu-3 cells. The architecture of the ANN is

215 illustrated in Figure 5c. Once a fully trained ANN is constructed, the backpropagation (i.e. 
216 differentiation of output classes with respect to input features) of the ANN would enable the

217 assignment of contribution scores to each input feature. Here, the prediction score is

218 distributed to each input feature in proportion to its contribution to the prediction with respect

219 to a certain baseline class (i.e. control, GlyH101 and Inh 172). Those inputs with high

220 prediction scores are considered to be significant markers as they contribute decisively on the

221 selected class.

The ANN model is tested on a 10-fold cross-validation set and the model performance is assessed through the metrics defined in Table 1. The accuracy of the validation set is estimated to be $93 \%$.

Table 1. Detailed Accuracy of the ANN by Class

\begin{tabular}{|l|r|r|r|r|r|r|l|}
\hline & TP Rate & FP Rate & Precision & Recall & F-Measure & $\begin{array}{l}\text { ROC } \\
\text { Area }\end{array}$ & Class \\
\cline { 2 - 8 } & 0.949 & 0.081 & 0.943 & 0.949 & 0.946 & 0.975 & CFTR101 \\
\cline { 2 - 8 } & 0.91 & 0.011 & 0.924 & 0.91 & 0.917 & 0.992 & CFTR172 \\
\cline { 2 - 8 } & 0.91 & 0.034 & 0.916 & 0.91 & 0.913 & 0.972 & Control \\
\hline Weighted Avg. & 0.933 & 0.059 & 0.933 & 0.933 & 0.933 & 0.976 & \\
\hline
\end{tabular}

227 The significant features extracted through backpropagation are the average amount of grey

228 intensity area, circularity and x-coordinates of the center of each vesicle (denoted as CenterX).

229 Figure 7A-D shows the significant feature distributions of the vesicles by class. 


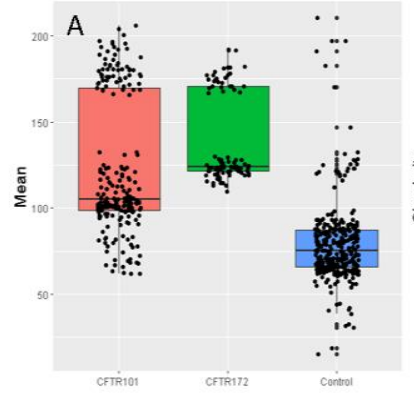

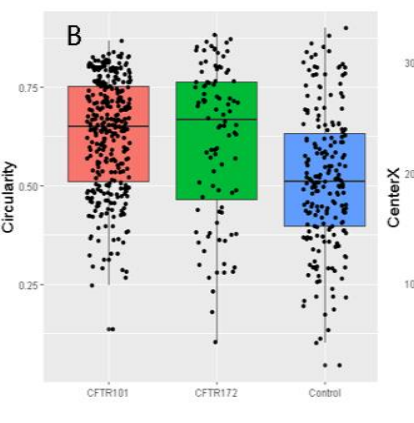
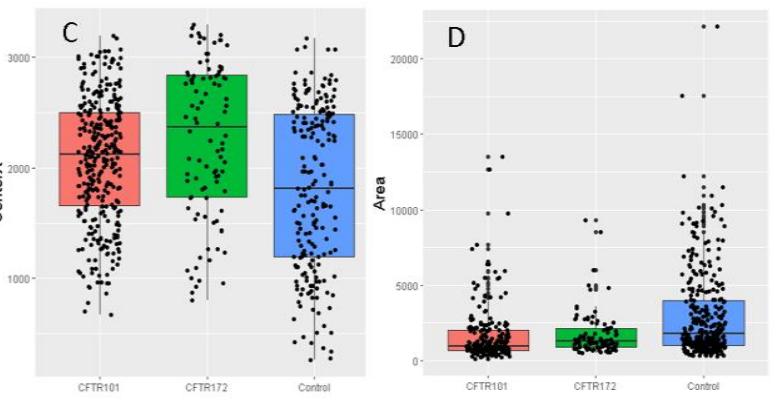

후 CFTR101 후 CFTR172

233 Figure 7. Filled and partially filled/empty secretory vesicle grey intensity (or electron dense

234 i.e., content), circularity, X-coordinates and area, in control Calu-3 cells and cells exposed to

CFTR inhibitors GlyH-101 and Inh172. A. The average amount of gray intensity B.

236 Circularity, C. X-coordinates of the center of each vesicle (Center X) and D. Area

237 distributions of the vesicles by class. The computational analysis have demonstrated that

238 changes in the aforementioned significant features can successfully lead to the differentiation

239 of control and CFTR-inhibited cells. In particular, due to the higher percentage of empty and

240 partially empty secretory vesicles in control cells (also demonstrated through the manual

241 morphometry analysis in Figure 4), the average amount of gray intensity in control cells is

242 observed to be less than the CFTR inhibited cells (Figure 7A).

244 Our computational results show that circularity and CenterX can further improve the

245 classification accuracy by distinguishing between GlyH101 and Inh 172 cells (Figure 7b-c). In

246 agreement with data obtained using manual morphometric analysis, our computational 
bioRxiv preprint doi: https://doi.org/10.1101/2020.05.26.117853; this version posted May 27, 2020. The copyright holder for this preprint

(which was not certified by peer review) is the author/funder, who has granted bioRxiv a license to display the preprint in perpetuity. It is made available under aCC-BY 4.0 International license.

248 Calu-3 cells. This may be due in part to the prevention of ion and water entry into vesicles for

249 hydration and consequent vesicle swelling required during cell secretion [38-44]. These results

250 further suggest that mucin secretion from Calu-3 cells involve CFTR function, both at the

251 secretory vesicle membrane to regulate vesicle water entry and hydration, and the additional

252 hydration of mucin at the porosome complex to facilitate secretion. 


\section{REFERENCE}

255 1. Schneider, S. W., Sritharan, K. C., Geibel, J. P., Oberleithner, H., Jena, B. P. (1997)

256 Surface Dynamics in Living Acinar Cells Imaged by Atomic Force Microscopy:

257 Identification of Plasma Membrane Structures Involved in Exocytosis. Proc. Natl. Acad.

258 Sci. USA. 94, 316-321.

2. Cho, S-J., Quinn, A. S., Stromer, M. H., Dash, S., Cho, J., Taatjes, D. J., Jena, B. P. (2002)

3. Cho, S-J., Wakade, A., Pappas, G. D., Jena, B. P. (2002) New structure involved in

4. Cho, S-J., Jeftinija, K., Glavaski, A., Jeftinija, S., Jena, B. P., Anderson, L. L. (2002) atomic force microscopy. Endocrinology 143, 1144-8. pore. Cell Biol. Int. 28, 699-708.

6. Cho, W. J., Jeremic, A., Jin, H., Ren, G., Jena, B. P. (2007) Neuronal fusion pore assembly requires membrane cholesterol. Cell Biol. Int. 31, 1301-1308. 
8. Jena, B. P., Cho, S-J., Jeremic, A., Stromer, M. H., Abu-Hamdah, R. (2003) Structure and composition of the fusion pore. Biophys. J. 84, 1-7.

9. Jeremic, A., Kelly, M., Cho, S-J., Stromer, M. H., Jena, B. P. (2003) Reconstituted Fusion

10. Cho, W-J., Jeremic, A., Jena, B. P. (2005). Direct interaction between SNAP-23 and Ltype calcium channel. J. Cellular \& Mol. Med. 9(2):380-386.

11. Jeremic, A.., Cho, W-J., Jena, B. P (2006). Cholesterol is critical to the Integrity of neuronal porosome/fusion pore. Ultramicroscopy 106:674-677.

12. Cho, W-J, Jeremic, A., Jin, H., Ren, G., Jena, B.P. (2007) Neuronal fusion pore assembly requires membrane cholesterol. Cell Biol. Int. 31:1301-1308.

13. Cho, W-J, Ren, G., Jena, B.P. (2008) EM 3D contour maps provide protein assembly at the nanoscale within the neuronal porosome complex. J. Microscopy 232:106-111. J. Cell Mol. Med. 13:365-372. three-dimensional contour map of protein assembly within the astrocyte porosome complex. Cell Biol. Int. 33:224-229.

16. Cho, W-J., Lee, J-S., Jena, B. P. (2010) Conformation states of the neuronal porosome complex. Cell Biol. Int. 34:1129-1132. 
bioRxiv preprint doi: https://doi. org/10.1101/2020.05.26.117853; this version posted May 27, 2020. The copyright holder for this preprint (which was not certified by peer review) is the author/funder, who has granted bioRxiv a license to display the preprint in perpetuity. It is made available under aCC-BY 4.0 International license.

292 17. Wang, S., Lee, J-S., Bishop, N., Jeremic, A., Cho, WJ., Chen, X., Mao, G., Taatjes, D.J.,

293 Jena, B.P. (2012) 3D organization and function of the cell: Golgi budding and vesicle

294 biogenesis to docking at the porosome complex. Histochem. Cell Bio. 137:703-718.

295 18. Lee J-S, Jeremic A, Shin L, Cho WJ, Chen X, Jena BP. (2012) Neuronal Porosome

proteome: Molecular dynamics and architecture. J. Proteomics. 75: 3 952-62.

297 19. Kovari LC, Brunzelle JS, Lewis KT, Cho WJ, Lee J-S, Taatjes DJ, Jena BP. (2014) X-ray

298 solution structure of the native neuronal porosome-synaptic vesicle complex: Implication in

299 neurotransmitter release. Micron 56: 37-43.

300 20. Lewis, K.T., Maddipati, K.R., Taatjes, D.J., Jena, B.P. (2014). Neuronal porosome lipidome.

$301 \quad$ J. Cell. Mol. Med. 18:1927-1937.

302 21. Hou X, Lewis KT, Wu Q, Wang S, Chen X, Flack A, Mao G, Taatjes DJ, Sun F, Jena BP.

303 (2013) Proteome of the porosome complex in human airways epithelia: Interaction with the cystic

304 fibrosis transmembrane conductance regulator (CFTR). J. Proteomics. 96: 82-91.

305 22. Rajagopal A, Kulkarni S, Lewis KT, Chen X, Maarouf A, Kelly CV, Taatjes DJ, Jena BP.

306 (2015) Proteome of the insulin-secreting Min6 porosome complex: Involvement of Hsp90 in its

307 assembly and function. J. Proteomics. 114: 83-92.

308 23. Drescher DG, Cho W-J, Drescher M. (2011) Identification of the porosome complex in the

309 hair cell. Cell Biol Int Rep. 18: 31-34. 
311 Zhvania MG. (2012) Hypokineitic stress and neuronal porosome complex in the rat brain: the

312 electron microscopic study. Micron 43, 9 :948-963.

313 25. Siskou L, Rostaining P, Lechaire JP, Boudlier T, Ohtsuka T, Fejtova A et al. (2012) Three-

314 dimensional architecture of presynaptic terminal cytomatrix. J. Neurosci. 27: 6868-6877.

315 26. Okuneva VG. Japarodze NJ. Kotaria NT, Zhvania MG. (2012) Neuronal porosome in the rat

316 and cat brain. Tsitoloiya. $54: 210-215$.

317 27. Okuneva VC, Japaridze NJ, Kotaria NT, Zhvania MG. (2012) Neuronal porosome in the rat

318 and cat brain. J. Cell Tissue Biol. 6 (1): 69-72.

319 28. Craciun C, Barbu-Tudoran L. (2013) Identification of new structural elements within

320 'porosomes' of the exocrine pancreas: a detailed study using high-resolution electron microscopy.

321 Micron 44: 137-142.

322

29. Cho S-J, Kelly M, Rognlien KT, Cho JA, Horber JKH, Jena BP. (2002) SNAREs in opposing

323 bilayers interact in a circular array to form conducting pores. Biophys. J. 83: 2522-2527.

324 30. Jeremic A, Kelly M, Cho J-H, Cho S-J, Horber JKH, Jena BP. (2004) Calcium drives fusion

325 of SNARE-apposed bilayers. Cell Biol. Int. 28: 19-31.

326 31. Jeremic A, Cho W-J, Jena BP. (2004) Membrane fusion: what may transpire at the atomic

327 level. J. Biol. Phys. \& Chem. 4: 139-142. 
32. Cho W-J, Jeremic A, Jena BP. (2005) Size of supramolecular SNARE complex: membrane-

33. Jeremic A, Quinn AS, Cho W-J, Taatjes DJ, Jena BP. (2006) Energy-dependent disassembly of self-assembled SNARE complex: observation at nanometer resolution using atomic force microscopy. J. Am. Chem. Soc. 128: 26-27.

334 the assembly and disassembly of SNAREs: the proteins involved in membrane fusion in cells.

335 Chem. Phys. Lett. 462: 6-9.

336 35. Shin L, Cho W-J, Cook J, Stemmler T, Jena BP. (2010) Membrane lipids influence protein 337 complex assembly-disassembly. J. Am. Chem. Soc. 132: 5596-5597.

338 36. Issa Z, Manke CW, Jena BP. Potoff JJ. (2010) $\mathrm{Ca}^{2+}$ bridging of apposed phospholipid bilayer 339 J. Phys. Chem. 114: 13249-13254.

340 37. Cho WJ, Lee J-S, Ren G, Zhang L, Shin L, Manke CW, Potoff J, Kotaria N, Zhvania MG,

341 Jena BP. (2011) Membrane-directed molecular assembly of the neuronal SNARE complex. $J$.

342 Cell. Mol. Med. 15: 31-37.

343 38. Jena BP, Schneider SW, Geibel JP, Webster P, Oberleithner H, Sritharan KC. (1997) Gi

344 regulation of secretory vesicle swelling examined by atomic force microscopy. Proc. Natl. Acad. 
347 BP. (2002) Aquaporin 1 regulates GTP-induced rapid gating of water in secretory vesicles. Proc.

Natl. Acad. Sci. USA. 99: 4720-4724.

40. Kelly M, Cho W-J, Jeremic A, Abu-Hamdah R, Jena BP. (2004) Vesicle swelling regulates

content expulsion during secretion. Cell Biol. Int. 28:709-716.

351

41. Jeremic A, Cho W-J, Jena BP. (2005) Involvement of water channels in synaptic vesicle

swelling. Exp. Biol. Med. 230: 674-680.

353

42. Shin L, Basi N, Lee J-S, Cho W-J, Chen Z, Abu-Hamdah R, Oupicky D, Jena BP. (2010)

Involvement of $\mathrm{vH}^{+}$-ATPase in synaptic vesicle swelling. J. Neurosci. Res. 88: 95-101.

43. Lee J-S, Cho W-J, Shin L, Jena BP. (2010) Involvement of cholesterol in synaptic vesicle

swelling. Exp. Biol. Med. 235: 470-477.

357

44. Chen Z-H, Lee J-S, Shin L, Cho W-J, Jena BP. (2011) Involvement of $\beta$-adrenergic receptor

$572-576$.

360

45. Taraska JW, Perrais D, Ohara-Imaizumi M, Nagamatsu S, Almers W. (2003) Secretory

361

granules are recaptured largely intact after stimulated exocytosis in cultured endocrine cells. Proc.

Natl. Acad. Sci. USA. 100: 2070-2075.

46. Aravanis AM, Pyle JL, Tsien RW. (2003) Single synaptic vesicles fusing transiently and 
47. Thorn P, Fogarty KE, Parker I. (2004) Zymogen granule exocytosis is characterized by long

6774-6779.

(2013) Proteome of the porosome complex in human airway epithelia: interaction with the cystic

fibrosis transmembrane conductance regulator (CFTR). J. Proteomics. 96: 82-91.

Review of Biochemistry 80: 613-643.

inhibitors. Curr. Pharm. Des. 19: 3529-3541. 
bioRxiv preprint doi: https://doi.org/10.1101/2020.05.26.117853; this version posted May 27,2020 . The copyright holder for this preprint

(which was not certified by peer review) is the author/funder, who has granted bioRxiv a license to display the preprint in perpetuity. It is made available under aCC-BY 4.0 International license.

383 54. Wang Z, Ji S. (2018) Smoothed Dilated Convolutions for Improved Dense Prediction. In

384 Proceedings of the 24th ACM SIGKDD International Conference on Knowledge Discovery \&

385 Data Mining. 2486-2495.

386

387 Author Contributions: B.P.J. developed the idea. B.P.J. and S.A. wrote the paper. B.S.L.

and K.T.L. performed the experiments. B.S.L., K.T.L. and R.R. carried out manual

morphometric analysis and prepared some of the figures. D.J.T performed the electron

microscopy. X.H and F.S performed the Ussing chamber assays. S.A performed machine

the manuscript.

394 Acknowledgements: Work presented in this article was supported in part by the National

Science Foundation grants EB00303, CBET1066661 (BPJ).

397 Competing Financial Interest: The authors declare no competing financial interest.

399 Corresponding Authors: bjena@med.wayne.edu (B.P.J); suzan.arslanturk@wayne.edu

$400 \quad$ (S.A)

401

402 ORCID

403 Bhanu Jena: 0000-0002-6030-8766

404 Suzan Arslanturk: 0000-0002-4554-4373 